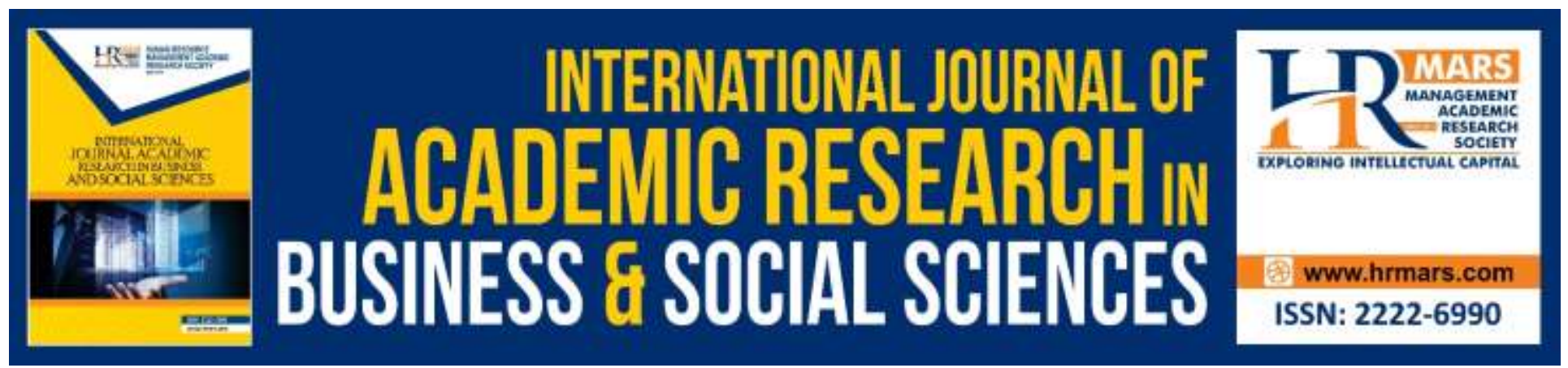

\title{
Innovation Capacity and Performance of Malaysian SMES
}

\section{Daljeet Singh Malkeet Singh, Norshafizah Binti Hanafi}

To Link this Article: http://dx.doi.org/10.6007/IJARBSS/v10-i2/6956

DOI:10.6007/IJARBSS/v10-i2/6956

Received: 21 January 2020, Revised: 01 February 2020, Accepted: 12 February 2020

Published Online: 29 February 2020

In-Text Citation: (Singh \& Hanafi, 2020)

To Cite this Article: Singh, D. S. M., \& Hanafi, N. B. (2020). Innovation Capacity and Performance of Malaysian SMES. International Journal of Academic Research in Business and Social Sciences, 10(2), 665-679.

Copyright: (C) 2020 The Author(s)

Published by Human Resource Management Academic Research Society (www.hrmars.com)

This article is published under the Creative Commons Attribution (CC BY 4.0) license. Anyone may reproduce, distribute, translate and create derivative works of this article (for both commercial and non-commercial purposes), subject to full attribution to the original publication and authors. The full terms of this license may be seen at: $\underline{\text { http://creativecommons.org/licences/by/4.0/legalcode }}$

Vol. 10, No. 2, 2020, Pg. 665 - 679

Full Terms \& Conditions of access and use can be found at http://hrmars.com/index.php/pages/detail/publication-ethics 


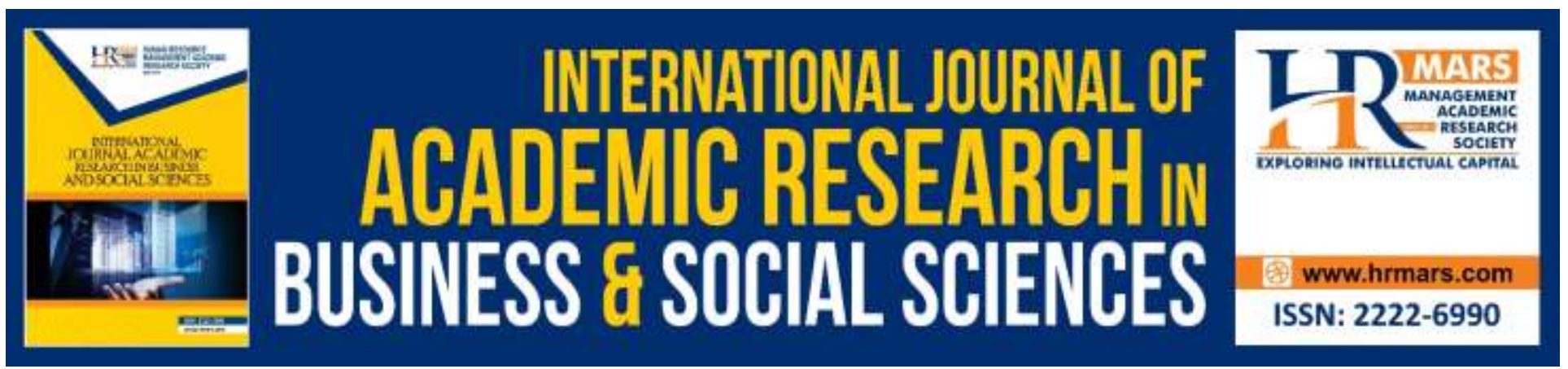

\title{
Innovation Capacity and Performance of Malaysian SMES
}

\author{
Dr. Daljeet Singh Malkeet Singh \\ Owner/Director, Acuity Business Solutions, No. 34, Jalan 1/154A, Taman Bukit Anggerik, 56000, \\ Cheras, Kuala Lumpur. \\ Email: dsgill19@Gmail.Com
}

\section{Dr. Norshafizah Binti Hanafi}

Senior Lecturer, University Utara Malaysia, No. 41-3, Jalan Raja Muda Abdul Aziz, Kampung Baru, 50300 Kuala Lumpur.

Email: norshafizah@uum.edu.my

\begin{abstract}
The study is designed to examine and analyze the effects of innovation capacity (IC) on firm performance (FP) of Small Medium Enterprises (SMEs) within the service industry, located within the State of Selangor, Malaysia. The populations of the respondents are owner managers of 150 SME firms, constituting 20\% response rate. Partial Least Squares Structural Equation Modeling (PLS-SEM) is utilized to examine the relationship. The evidence shows that IC has a significant and positive impact on overall FP. Firms' that emphasizes innovativeness in all aspects indicates' an improved overall performance. The study contributes to existing understanding highlighting important aspects of innovation within an organization that affects overall performance and ensures sustainability and growth.
\end{abstract}

Keywords: Product Innovation, Process Innovation, Marketing Innovation, Organizational Innovation, Mortality, SMES Performance, Malaysia

\section{Introduction}

The vital role and significance of SMEs for thriving the economic and market development in Malaysia is widely acknowledged. The benefits gained from SMEs in Malaysia encompass various aspects, such as, income tax's revenue, exportation of goods and services, employment creation along with, reduction of unemployment index percentage, mitigation of poverty, economic empowerment, and the wider supply of economic opportunities and wealth. However, the most important factor and 
INTERNATIONAL JOURNAL OF ACADEMIC RESEARCH IN BUSINESS AND SOCIAL SCIENCES Vol. 10, No. 2, Feb, 2020, E-ISSN: 2222-6990 @ 2020 HRMARS

reason for encouraging SMEs in Malaysia is due to, the creation of employment and its contribution towards gross domestic product (GDP) of the economy.

Just as any other nation, Malaysian government has put in place various assistance to cater to the development of the nation's economy through programs, incentives and schemes encouraging larger pool of people to venture into entrepreneurship, especially in the SME sector. These had resulted in an increase of establishment of enterprises yet it had equally contributed to high number of failure rates.

In his research, Van Praag (2003) stressed, whilst the number of establishments is high, the survival of these firms is questionable. These findings are similar to many past surveys done the world over and mortality of these firms' are high especially within the initial five (5) years of business operation (EIM, 2010 \& US SBA, 2014). Research by Kampschroeder, et al., (2008) highlights the undesirable wave of economic fallout of failed small businesses. Similarly, Liao et. al., (2008) \& US SBA (2009) relates that, small businesses experienced discontinuance due to growing challenges, strong competition from large firms and globalization, as statistics reveals that, only $76 \%$ of startups stay operational beyond two (2) years, $47 \%$ beyond four (4) years, and only $38 \%$ beyond six (6) years, respectively. Similarly, Tan et al. (2009) stated that, between $50 \%-80 \%$ of small businesses fails within a short span of operation.

$36.3 \%$ of the Malaysian's gross-domestic-product (GDP) is channeled by SMEs, along with $17.8 \%$ of the nation's export, and accounts for 65.5\% of total employment (SME Annual Report, 2015/16). Malaysian SME sector equally plays an import role in youth and gender employment, indirectly attending to urban and rural poor by promoting entrepreneurship. The significant and glaring contribution by SMEs results in its attracting considerable attention among academicians, trade organization, investors, researchers and other agencies. Entrepreneurship is on a rising trend as stated by Gartner \& Shane (1995) and Thornton (1999), and according to Sathe (2003), the economy of the current world is entrepreneur oriented, hailing entrepreneurs as the new supporter of competiveness and economic development. The Malaysian government recognizes that, key success factor for SMEs is innovativeness, since the emergence of newer technologies and products have influenced the way businesses are conducted (NSDC, 2007). Oke et. al., (2003) asserts that, encouraging creativity and innovation in entrepreneurship is also the agenda of governments in the member countries of the 'Organization for Economic Co-operation and Development' (OECD) and transitional, emerging and developing economies, as entrepreneurs are the means of growth, pooling capital for funding investment, innovativeness, along with, necessary skill-sets. Ever since the 1990's, high importance of innovativeness for competitiveness and long-term survival has be reported by scores of researchers (Ancona \& Caldwell, 1992; Kim \& Mauborgne, 2007), which stress that, managers at all level has to be concerned and be anxious about promoting innovation. Numerous current researchers agreed that, managing innovation is fundamental for the survival of the firms and businesses.

The study specifically explore and focuses on 4 dimensions of innovation capability (product, process, marketing and organizational) and its' effects and relationship towards the firm's performance in 
INTERNATIONAL JOURNAL OF ACADEMIC RESEARCH IN BUSINESS AND SOCIAL SCIENCES

Vol. 10, No. 2, Feb, 2020, E-ISSN: 2222-6990 ¿ 2020 HRMARS

order to minimized mortality rates, ensure survival, maintain sustainability and to enhance further growth.

\section{Problem Statement}

\section{SME Mortalities}

Table 1.1 shows that $97.3 \%$ of the firms were SMEs, totaling 645,136 registered companies in Malaysia.

Table 1.1

SME: By Sector in Numbers.

\begin{tabular}{|c|c|c|c|c|}
\hline Sector & $\begin{array}{c}\text { Total } \\
\text { Establishments } \\
\text { (a) }\end{array}$ & Total SMEs (b) & $\begin{array}{c}\text { Percentage (\%) } \\
\text { of SMEs over } \\
\text { Total } \\
\text { Establishments } \\
\text { (b)/(a)*100 }\end{array}$ & $\begin{array}{c}\text { Total Employment } \\
\text { by SMEs }\end{array}$ \\
\hline Overall Total & 662,939 & 645,136 & 97.3 & $3,669,259$ \\
\hline Services & 591,883 & 580,985 & 98.1 & $2,610,373$ \\
\hline Manufacturing & 39,669 & 37,861 & 95.4 & 698,713 \\
\hline Agriculture & 8,829 & 6,708 & 76.0 & 78,777 \\
\hline $\begin{array}{l}\text { Construction } \\
\text { Mining \& }\end{array}$ & 22,140 & 19,283 & 87.1 & 275,631 \\
\hline Quarrying & 418 & 299 & 71.5 & 5,765 \\
\hline
\end{tabular}

Source: SMECorp, 2015.

Performance of Malaysian SMEs is crucial for firm's survival and that, it is equally critical to the overall economy on the whole. Malaysian SME firms are faced by many challenges, particularly in the light of changing global markets, including the ability to compete globally and move up the value chain (UNDP, 2007). Research by Avermaete et.al (2003), reveals that, being innovative and embarking on innovation is important for SMEs as they need to constantly introduce new products, and develop new processes in order to explore and expand wider markets. Despite large numbers of SMEs in various sectors and industries, mortality rate of these firms are alarmingly high. Table 1.2 shows number of companies wound-up through voluntary action by members and creditors, while the rest of the firms were wound-up by court order. As for companies dissolved through strike-off process, it were through voluntary submission and the rest were initiated by the Registrar to remove dormant companies. 
INTERNATIONAL JOURNAL OF ACADEMIC RESEARCH IN BUSINESS AND SOCIAL SCIENCES Vol. 10, No. 2, Feb, 2020, E-ISSN: 2222-6990 @ 2020 HRMARS

Table 1.2

Total Number of Firms failures

\begin{tabular}{lccc}
\multicolumn{1}{c}{ Years } & $\mathbf{2 0 1 5}$ & $\mathbf{2 0 1 4}$ & $\mathbf{2 0 1 3}$ \\
\hline Companies wound up \& Struck-Off & & & \\
Termination of businesses & 33,006 & 30,924 & 26,700 \\
& 35,450 & 29,966 & 18,161 \\
\hline
\end{tabular}

Source: SMECorp, 2016.

As shown in Table 1.2, records shows that, on an average, the number of businesses terminated per year over the last three years (2013 - 2015) stands at 27,859, which is an alarming increase in the number of small businesses that were terminated (SSM annual report, 2016) in 2015.

Based on findings of Noor Hazlina \& Pi-Shen (2009), failure rates of Malaysian SMEs are about three (3) times as compared to other countries, such as Australia. Therefore, it is critical for Malaysian SMEs, to reduce vulnerability of global economic shocks and maneuver to enhance firm's performance in order to remain afloat and survive. These failure rates drastically and directly and or indirectly affects the contribution towards Malaysian economy in terms of GDP, job employment opportunities, productivity and value-added offerings in the country. Firm failures affects the environment and society in which they operate and further adds woe to economic and social issues in regards to job unemployment, inflation, and consequently, bankruptcy of businesses, which may result in social ill and unrest.

Siringoringo et al. (2009) found that, some of the reasons for terminations of firms as well as, shutting-down problems experienced by the SMEs are due to challenges and factors related with either the followings concerns; - difficulties in obtaining external financing, problems related to sales and marketing, issues with overall management and internal financial management. Ali \& Ndibisi (2006) \& Mohd Khairuddin Hashim (2007) stated that the shortage of resources affects the firm's performance. Lucky \& Olusegun (2012) highlighted low productivity, lack of managerial capabilities, access to credit, difficulty in accessing technology and heavy regulatory burden against SMEs. Gilmore et al. (2006) bring to light similar findings, that is, resource constraints and limitation being key factors. Chong (2012) further stated that, while having various government's assistance and programs targeting new entrant in SMEs, yet the mortality rate is growing higher.

The gaps observed from various studies are, the lack of investigations in Southeast Asia and in Malaysia in particular, on;- i) Innovative Capacity (IC) consisting of all four (4) suggested dimensions (product, process, marketing and organizational), and its effect on SME firms' performance, ii) To provide a new insight to the relationship these variables, and that, iii) To further provide validations and verification for generalization purpose on previous research findings. 
INTERNATIONAL JOURNAL OF ACADEMIC RESEARCH IN BUSINESS AND SOCIAL SCIENCES

Vol. 10, No. 2, Feb, 2020, E-ISSN: 2222-6990 @ 2020 HRMARS

\section{Literature Review}

\section{Firm's Performance}

The word performance is not new, despite the frequency of usage yet, its meaning is relative. In many small business literatures, SMEs performance has be researched upon by a number of researchers and that most research investigating SMEs performance with a varied number of variables. According to Moullin (2007), SMEs' performance is seen and viewed as, how firm delivers value to its stakeholders, as well as, their customers. Similarly, Neely et. al., (1995) views that, firm performance is a concept often discussed in studies, yet has no single definition. Firm performance may be defined as the process of quantifying activity and action of firm which leads to achievement of its goals and objectives, through satisfying its customers and stakeholders. These achievements are through an efficient and effective performance of business operation as compared to its competitors (Neely, 2005). Therefore, firm's performance can be defined as the measurement of how well its goals and objectives are achieved (Penrose, 1959). This study defines SMEs firm performance as the ability of firm to effectively and efficiently exploit available resources to ensure survival, yet fulfill customer satisfaction and contribute towards creation of employment. Alenka (2014) stated that, in order to foster better firm performance, entrepreneurs has to have the abilities of being 'open to ideas and views', 'constantly seek feed-backs' and 'continuously engages in learning'. Being receptive towards learning something new, to seek for new business opportunities and to gather feedback to their ideas for improvement, is a positive influence towards firm performance.

\section{Innovation Capacity}

As indentified by Roberts, Baker \& Walker (2005), innovation originates from the Latin word known as 'innovare', suggest to mean, being new, to take something new, doing existing things in a new way, or doing something new in response to changes. From an organizational perspective, a fitting definition for innovation is as given by Luecke, Richard \& Katz (2003): "Innovation is generally understood as the introduction of a new thing or method. Innovation is the embodiment, combination, or synthesis of knowledge in original, relevant, valued new products, processes, or services". (p. 1). In view of the above mentioned statements, one may suppose that, innovation and innovativeness either directly or indirectly affects firm's performance positively and that, innovation comes in through varying approaches, and are subject to entrepreneurs and firm's strategic orientation. Innovation capacity can be categorized as a multidimensional construct as it has main four different nature of constructs comprising product innovation, process innovation, organizational innovation, and marketing innovation (Varis \& Littunen, 2010). Therefore, innovation capability (IC) is an overall firms' innovativeness of product, process, marketing and organizational strategy to steer organization toward better performance.

\section{Product Innovation}

Based on the findings of Gopalakrishnan \& Damanpour (1997) \& Langley et. al., (2005), product innovation is defined as, the creation of a new product out of new resources or materials (totally new product) or the modification of existing products (alteration to enhance existing version of current product) to fulfill customer satisfaction. Similarly, the definition also refers to, the introduction of new services or product in order to satisfy existing market or consumers or to create new markets (Wang \& Ahmed, 2004; Wan et al., 2005). Myers \& Marquis (1969) stated that, exploitation of new 
ideas will result in innovation of new products. Similarly, Craig \& Hart (1992) stressed that, product innovation provides and increases variety of choices for products. OECD (Oslo Manual, 3rd edition, 2005) definition specifies product innovation as, the introduction of a good or service that is new or significantly improved with respect to its characteristics or intended uses. This includes significant improvements in technical specifications, components and materials, incorporated software, user friendliness or other functional characteristics. Product innovations can utilize new knowledge or technologies, or can be based on new uses or combination of existing knowledge or technologies. Product innovations include both the introduction of new goods or services and significantly improvements in the functional or user characteristics of existing goods and services. New products are goods and services that differ significantly in their characteristics or intended uses from products previously produced by the firm. The first microprocessors and digital cameras were examples of new products using new technologies. The first portable MP3 players, which combined existing software standards with miniaturized hard-drive technology, was a new product combining existing technologies.

The development of new use for a product with only minor or major changes to its technical specifications is a product innovation. An example is the introduction of a new detergent using an existing chemical composition that was previously used as an intermediary for coating production only. Product innovations in services can include significant improvements in how they are provided (efficiency and speed), the addition of new functions or characteristic to existing services or the introduction of entirely new services. Examples are significant improvements in Internet banking services, such as greatly improved speed and ease of use, or the addition of home pick-up and dropoff services that improve customer access for rental cars. Providing on-site rather than remote management contact points for outsourced services is an example of an improvement in service quality.

\section{Process Innovation}

Generally, process innovations are the reengineering of, and enhancement of internal operation of business processes (Cumming, 1998). This process innovation consist various parts of a firm's operations, such as, management, manufacturing, technical design, research \& development (R\&D), and business activities (Freeman, 1982). Similarly, Oke et al. (2007) stated that, process innovation relates with the improvement in or creation of techniques and the development in process or system. Zhuang et. al., (1999) agreed that, innovation in technology, skill, techniques, system and procedure, which is used in the process of converting or to transform inputs into outputs. In a production activity, process innovation can be referred to as, improved or new methods, devices, tools, and knowledge in creation of a product (Gopalakrishnan \& Damanpour, 1997; Langley et al., 2005; Wan et al., 2005; Oke et al., 2007). OECD (Oslo Manual, 3rd edition, 2005) specifies process innovation as, the implementation of a new or significant improved production or delivery method, which includes significant changes in techniques, equipment and or software. Process innovation can be intended to decrease unit costs of production or delivery, to increase quality, or to produce or deliver new or significantly improved products. It include new or significantly improved methods for creation and provision of services, which involve significant changes in equipment and software used in servicesoriented firms or in the procedures or techniques that are employed to delivery services. An example 
is the introduction of GPS tracking devices for transportation services, the implementation of a new reservation system in a travel agency, and the development of new technique for managing projects in a consultancy firm. Process innovation also covers new or significantly improved technique, equipment and software in ancillary support activities, such as purchasing, accounting, computing and maintenance. The implementation of new or significantly improved information and communication technology (ICT) is a process innovation if it is intended to improve the efficiency and or quality of an ancillary support activity. Production methods involve the technique, equipment and software used to produce goods or services. An example of new production methods are the implementation of new automation equipment on a production line or the implementation of computer-assisted design for product development. Delivery methods concern the logistics of the firm and encompass equipment, software and technique to source inputs, allocate supplies within the firm, or deliver final products. An example of a new delivery method is the introduction of a barcoded or active RFID (radio frequency identification) goods-tracking system.

\section{Marketing Innovation}

As explained by Johne (1999), in order to meet a customer's buying preference, therefore market innovation is about market selection and market mix. Firms has to continuously be engaged in market innovation due to state-of-the-art marketing tools, such as the internet making it possible for competitors to reach potential customers across the globe instantly. Likewise, Rodriguez-Cano et al. (2004) asserts that, market innovation plays a crucial role in fulfilling market needs and at the same time, responding to market opportunities. Therefore, any market innovation has to be directed at meeting customers' demand and satisfaction (Appiah-Adu \& Satyendra, 1998). OECD (Oslo Manual, 3 rd edition, 2005) specifies marketing innovation as, the implementation of a new marketing method involving significant changes in product design or packaging, product placement, product promotion and pricing, aimed at better addressing customer needs, opening up new markets, or newly positioning a firm's product on the market, with the objective of increasing the firm's sales. The distinguishing feature of a marketing innovation compared to other changes in a firm's marketing instruments is the implementation of a marketing method not previously used by the firm. It must be part of new marketing concept or strategy that represents a significant departure from the firm's existing marketing methods. The new marketing method can either be developed by the innovating firm or adopted from other firms or organizations. This new marketing method can be implemented for both new and existing products.

An example is, new marketing method in product placement, primarily involving introduction of a new sales channels, methods used to sell goods and services to customers which deals mainly with efficiency. Examples of marketing innovations in product placement are the introduction for the first time of a franchising system, of direct selling or exclusive retailing, and of product licensing. New marketing methods in product promotion involve the use of new concepts for promoting a firm's good and services. Examples are, the first use of a significantly different media or technique - such as product placement in movies or television programs or the use of celebrity endorsement. Branding such as the development and introduction of a fundamentally new brand symbol, intended to position the firm's product on a new market or give the product a new image. Yet, the introduction 
INTERNATIONAL JOURNAL OF ACADEMIC RESEARCH IN BUSINESS AND SOCIAL SCIENCES Vol. 10, No. 2, Feb, 2020, E-ISSN: 2222-6990 @ 2020 HRMARS

of a personalized information system such as, loyalty cards, to tailor the presentation of products to the specific needs of individuals.

\section{Organizational Innovation}

As identified by OECD, (Oslo Manual, 3rd edition 2005), organizational innovations is, the implementation of a new organizational methods in the firm's business practices, workplace organization or external relations and that organizational innovations can be intended to increase a firm's performance by reducing administrative costs or transaction costs, improving workplace satisfaction (and thus labor productivity), gaining access to non-tradable assets (such as non-codified external knowledge) or reducing costs of supplies. Distinguish features of organizational innovations are, implementation of new methods (in business practices, workplace organization or external relations) that has not been used before in the firm and is the result of strategic decision taken by the management. Organizational innovations in business practices involve the implementation of a new method for organizing routines and procedures for conduct of work.

These include, for example, the implementation of new practices to improve learning and knowledge sharing within the firm. An example is the first implementation of practices for codifying knowledge such as, establishing databases of best practices, lessons and other knowledge, so that they are now more easily accessible to others, and implementation for employee development and improving worker retention, such as education and training systems. Other examples are the first introduction of management systems for general production or supply operations, such as supply chain management systems, business re-engineering, lean production, and quality-management systems.

An example or organizational innovation in workplace organization is the first implementation of an organizational model that gives the firm's employees greater autonomy in decision making and encourages them to contribute their ideas, achieved through decentralization of group activity and management control or the establishment of formal or informal work teams in which individual workers have more flexible job responsibilities.

Innovation is the realization of something new. It is a product, a process, a marketing method or even an organizational change to make a difference and improve the activities of the enterprise. It adds value for the customer. This improvement ultimately will have a positive economic impact within the organization. In view of all that has been mentioned so far, one may suppose that, innovation and innovativeness either directly or indirectly affects firm's performance positively and that, innovation comes in through varying approaches, and are subject to entrepreneurs and firm's strategic orientation.

The literature presented above leads to the development of the following hypothesis: -

\footnotetext{
H1: There is a relationship between Innovative Capacity and SMEs Performance (Innovative capacity - SMEs Performance).
} 
INTERNATIONAL JOURNAL OF ACADEMIC RESEARCH IN BUSINESS AND SOCIAL SCIENCES Vol. 10, No. 2, Feb, 2020, E-ISSN: 2222-6990 @ 2020 HRMARS

\section{Research Methodology}

The approach of this research is quantitative and that the measurement utilized were empirically tested. The independent variables of the study are, product innovation, process innovation, marketing innovation and organizational innovation. The dependent variable is firm performance. Descriptive as well as, inferential statistics methodology for data analysis was used for the research. Inferential statistics utilized to infer about the population from which the data is obtained from (Singh, 2007), explaining and summarizing given set of data, whereas descriptive analysis to further describe and explain the related data. On collection of the raw data, the respondent's questionnaire was coded and subsequently computed into the Statistical Package software for Social Science (SPSSv22 and SmartPLSv3) for data analysis.

Data were collected from 150 SMEs firms within the state of Selangor. Multiple approach of data collection through survey questionnaire were utilized, which were as follows; postal mail, whatsApp smartphone's application, participation in events organized by SMECorp Malaysia and an online survey via emails. The independent and the dependent variables of the study were measured by a five-point Likert-type scales. To test the reliability of the results, a Cronbach's $(\alpha)$ alpha test were performed to ensure reliability of the questionnaires. The researcher investigated the effects and affects of, product, process, marketing and organizational innovation on SME's performance, as depicted on figure 1.1 below.

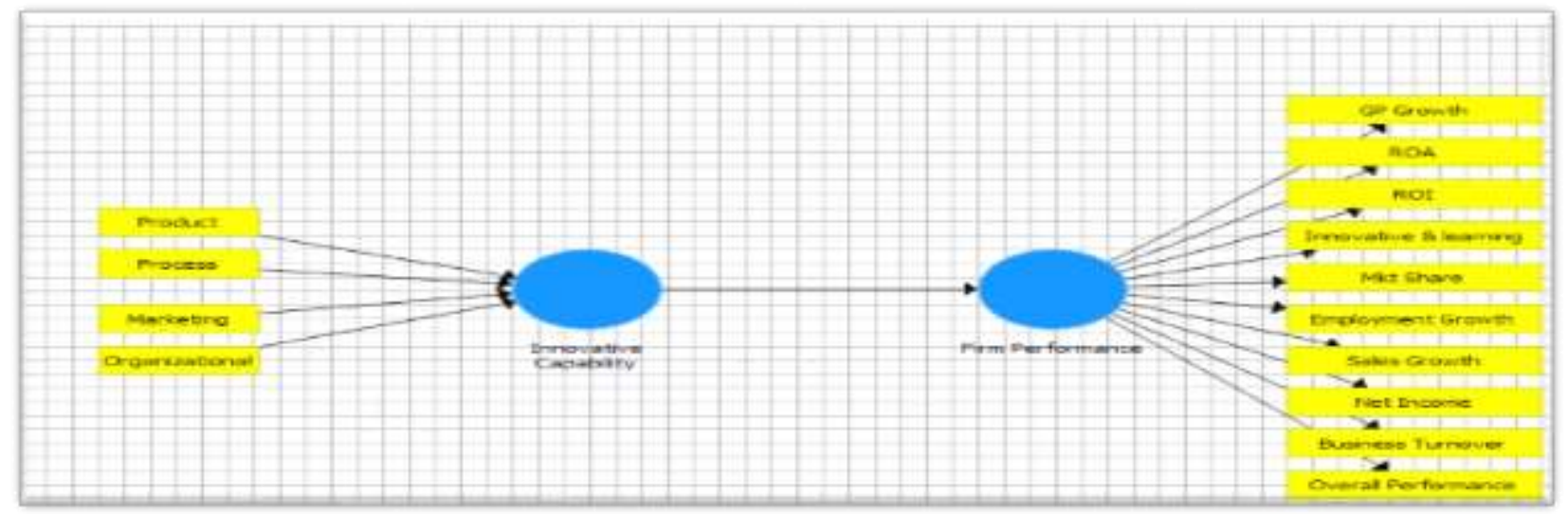

Figure 1.1

Research Framework

\section{Results and Discussion}

There is a positive relationship between (IC) innovation capacity (product innovation, process innovation, marketing innovation and organizational innovation) and performance of SME firms. Results as reflected in Table 1.3 indicate that the hypothesis is supported with beta 0.395, T-value 3.439, P-value 0.001 and effect size 1.427. Therefore, it indicates that SMEs that are implementing IC significantly and positively related to better SMEs firm performance in Malaysia, which is consistent with the hypothesis. With the value of $R^{2}$ for SMEs' performance of 0.588 , and the results of predictive relevancy indicated that the value of $Q^{2}$ for SMEs' performance is 0.433 , the findings and results has proven that the research model is and a reliable basis to measure for SMEs' performance through innovation capability (IC). 
INTERNATIONAL JOURNAL OF ACADEMIC RESEARCH IN BUSINESS AND SOCIAL SCIENCES Vol. 10, No. 2, Feb, 2020, E-ISSN: 2222-6990 @ 2020 HRMARS

Table 1.3

Direct relationships results

Path Coefficient Direct Relationship

\begin{tabular}{cccccccccc}
\hline Hypothesis & $\begin{array}{c}\text { Construct } \\
\text { Path }\end{array}$ & $\begin{array}{c}\text { Std } \\
\text { Beta }\end{array}$ & $\begin{array}{c}\text { Std } \\
\text { Error }\end{array}$ & $\begin{array}{c}\text { T- } \\
\text { Test }\end{array}$ & $\begin{array}{c}\text { P- } \\
\text { Values }\end{array}$ & $\mathbf{R}^{\mathbf{2}}$ & $\mathbf{f}^{\mathbf{2}}$ & $\mathbf{Q}^{\mathbf{2}}$ & Decision \\
\hline H1 & IC-FP & 0.395 & 0.093 & 3.439 & 0.001 & 0.588 & 1.427 & 0.433 & Supported
\end{tabular}

Implementation of innovation strategies is not an easy task for MSE (Micro \& Small Enterprises), as they face limited access to technology, and to economic resources. Kalin (2014) stated that, for innovation to grow, it needs an 'intensive networking practices' which includes partnerships and joint research with laboratories and the universities. It entails a practice of developing an ever-expanding network of knowledge and technological capabilities and that, these small innovative firms are patent-intensive, which provided a competitive edge ensuring partnership and growth. Therefore, innovation is internally-oriented strategies (process improvement) and positively contributed towards firm's performance. Externally-oriented strategy (management experience with, possession of unique product and competitive advantage) is equally positively related to performance.

In general, SMEs are very diverse and that, policy-makers should steer clear of collective consideration and that R\&D policy is not enough, thus be complemented along with other policies. It is argued that (US SBA, 2009), these policies ought to tackle a variety of objectives, such as, that it; (i) Must facilitate access to other innovative inputs, in addition to R\&D, (ii) Support company-wide innovation, (iii) Encourage skill-enhancement and human resources practices, (iv) Promote innovative networking and rewarding supplier-user relationship, and (v) Generate and create the needed framework conditions to facilitate spillovers from bigger firms, universities and or, research centers for SMEs.

\section{Conclusion}

Results of the empirical study and other past research concludes' that, innovativeness generally contributes positively to firm's performance. Therefore, it is essential that SME entrepreneurs and or owners-managers acknowledges' the importance of innovation in enhancing firm performance. Finding equally indicates that being innovative is an effective influencing factor for firm performance. It is recommended that, in order to enhance firm's performance, SME owner-managers should be creative in managing various dimension of innovation within the firm. The four key dimensions that generally reflect positively on firm performance are; product innovation, process innovation, marketing innovation and organizational innovation. The empirically researched results obtained from this study matches with the findings of past studies which states that innovation capability has positive effect and influence on firm performance (David et. el., 2007; Enkel et. el., 2009; Minna, 2014; Mayanyn \& Maria, 2016). The obtained results' findings further confirms and validate the research question and that in general it provides additional support for the contention of the Resource-based-view (RBV) as a theory on firm's strategic orientation by confirming the positive 
influence of the; valuable, rare, imperfectly imitable and non-substitutable (VRIN) resources on the performance of firm.

Findings of this study equally suggest and strongly encourage SMEs to embrace an innovative culture that supports a holistic view of the business. In practical term, developing an innovative culture to produce quality products, and services, clearly support SMEs firm performance. Focusing on a longterm innovative-mindset to ensure novelty of their offerings is vital for excellence and competitive advantage. On a final note, entrepreneur or owner-managers has to have the ability to identify opportunities or mismatches in the market, thus a focus on niches, a personal passion for their business or industry with the ability to communicate firm's vision. Additionally, owner-managers must ensure that firm produces an innovative product or service, along with a business that makes a positive impact in the community, beyond pure profits, along with the desire to engage with policy makers to shape agendas related to creation of jobs, financing and matters concerning challenges faced by SMEs.

Finally, as stated and highlighted in the literature review, innovation consist of interconnected components of product innovations, process innovations, marketing innovations and organizational innovations, and that all these fundamentals permit firms to be bold in taking business decisions in response to environment change, market orientation, competitive environment, and or drive markets. Lastly, result of the research emphasizes the importance of SMEs to possess innovativemindset, to ensure and realized better firm's performance. In conclusion, the findings suggest that SMEs, in the context of Malaysia, has to put emphasis on innovation especially on products, processes, marketing and organizational in order to assist firm recognize more business opportunities, create newer market and opportunities, increase and expand market, and take business risk to attain improved performances.

\section{Contribution, Limitation and Future Research}

Finding supports the research framework and contributes to the Resource-Based-View (RBV) theory, highlighting that the performance of firm is influenced by the firm's bundle of intangible and tangible resources. This study equally provides an opportunity to advance our knowledge on understandings of the relationship between innovative capacity (IC) and SMEs firm performances (FP). All four (4) dimensions of innovation are being explored; namely product innovation, process innovation, marketing innovation and organizational innovation. Findings equally demands that policy makers should encourage SME firms to pursue innovations by luring these firms through more aggressive incentives.

The study also contains some interesting findings that would provide for subsequent starting point for further studies. Secondly, the study embarked on a cross-sectional design, capturing data at one specific point-in-time. Due to cross-sectional method, it restricts in proving relationship between the variable (Sekaran \& Baugie, 2010). In view of this limitation, and to gauge long-term behaviors of SME firms, longitudinal study is suggested for future research. Thirdly, there are other aspects and variables that may moderate or mediate the relationship, therefore further studies should identify these aspects for further exploration. Lastly, the finding contributes new insights to the relationship 
INTERNATIONAL JOURNAL OF ACADEMIC RESEARCH IN BUSINESS AND SOCIAL SCIENCES

Vol. 10, No. 2, Feb, 2020, E-ISSN: 2222-6990 @ 2020 HRMARS

between the above said variable, to the body of knowledge and managerial or practitioner's perspective within the Malaysian context.

\section{References}

Alenka, S. (2014). Determinants of SME performance: The impact of entrepreneurial Openness and Goals. Economic \& Social development, 7th, International Scientific Conference, New York City.

Ancona, D. G., \& Caldwell, D. F. (1992). Demography and design: Predictors of new product team performance. Organization Science, 3(3), 321-341.

Saleh, A. S., \& Ndubisi, N. O. (2006). An evaluation of SME development in Malaysia. International Review of Business Research Papers, 2(1), 1-14.

Appiah-Adu, K., \& Satyendra, S. (1998). 'Customer Orientation and Performance: A Study of SMEs. Management Decisions, 36(6), 385-94.

Avermaete, T., Viaene, J., Eleanor, J., Morgan, N. C. (2003). Determinants of Innovation in Small Food Firms. European Journal of Innovation Management, 6(1), 8-17, http://doi.org/10.1108/14601060310459163

Chong, W. Y. (2012). Critical Success Factors for Small and Medium Enterprises: Perceptions of Entrepreneurs in Urban Malaysia. Journal of Business and Policy Research. vol. 7 (4), pp. 204215.

Craig, A., \& Hart, S. (1992). 'Where to Now in New Product Development Research,' European Journal of Marketing, 26(11), 1-49.

Cumming, B. S. (1998), "Innovation overview and future challenges", European Journal of Innovation Management, 1(1), 21-9.

David. R. L., Ross. L. C., \& Terry. R. S. (2007). Inter-relationship between innovation and market orientation in SMEs. Management Research New,30(12), 878-891.

Enkel, E., Gassmann, O., \& Chesbrough, H. W. (2009). Open R\&D and open innovation: Exploring the phenomenon. Journal of Research \& Development Management, 39(4), 311-316.

EIM. (2010). Annual Report on EU Small and Medium-sized Enterprises. Retrieved from, http://www.ec.europa.eu

Freeman, C. (1982). The Economics of Industrial Innovation, (2nd ed.), Frances Printer, London, UK.

Gartner, W. B., \& Shane, S. A. (1995). Measuring entrepreneurship over time. Journal of Small Business, 12(4), 11-32.

Gopalakrishnan, S., \& Damanpour, F. (1997). 'A Review Economics of Innovation Research in Sociology and Technology Management,' Omega, 25(1), 15-28.

Gilmore, A., Carson, D., \& Rocks, S. (2006). Networking in SMEs: Evaluating its contribution to marketing activity. International Business Review., 15, 278-293.

Johne, A. (1999). Successful Market Innovation. European Journal of Innovation Management, 2(1), 6-11.

Kalin, F. Z. (2014). Small innovative companies make a big difference. European View, 13, 161-7.

Kampschroeder, K. F., Ludwig, N., Murray, M. A., \& Padmanabhan, P. (2008). The stitch house: A case of entrepreneurial failure. Journal of the International Academy for Case Studies, 14(3), 3137.

Kim, W. C., Mauborgne, R. (2007), Blue ocean strategy. Leadership Excellence. 
INTERNATIONAL JOURNAL OF ACADEMIC RESEARCH IN BUSINESS AND SOCIAL SCIENCES

Vol. 10, No. 2, Feb, 2020, E-ISSN: 2222-6990 @ 2020 HRMARS

Langley, D. J., Pals, N., \& Ort, J. R. (2005). 'Adoption of Behaviour: Predicting Success for Major Innovations,' European Journal of Innovation Management, 8(1), 56-78.

Liao, J., Welsch, H., \& Moutray, C. (2008). Start-up resources and entrepreneurial discontinuance: The case of nascent entrepreneurs. Journal of Small Business Strategy, 19(2), 1-15.

Lucky, E. O., \& Olusegun, A. I. (2012). Is small and medium enterprises (SMEs) an entrepreneurship? International Journal of Academic Research in Business and Social Sciences, vol. 2, pp. 487496.

Mayanyn, L. M., \& Maria, T. O. F. (2016). Identification of Innovation Capabilities for Micro and Small Enterprise in Morelos, Mexico. Review of Business \& Finance Studies, 7(1), 79-92.

Minna, S. (2014). Innovation capability for SME success: Perspective of financial and operational performance. Journal of Advance in Management Research.

Hashim, M. K. (2007). SMEs in Malaysia: A Brief Handbook. Petaling Jaya: August Publishing.

Moullin, M. (2007). Performance measurement definitions: Linking performance measurement and organizational excellence. International Journal of Health Care Quality Assurance, 20(3), 181183.

Myers, S., \& Marquis, D.G. (1969). 'Successful Industrial Innovations,' National Science Foundation, Washington, DC.

Neely, A., Gregory, M., \& Platts, K. (1995). Performance measurement system design: A literature review and research agenda. International Journal of Operations \& Production Management, 15(4), 80-116.

Neely, Andy. (2005). The Evolution of Performance Measurement Research - Developments in the Last Decade and a Research Agenda for the Next. International Journal of Operations \& Production Management, 25, 1264-1277.

Ahmad, N. H., \& Seet, P. (2009), Dissecting behaviours associated with business failure: A qualitative study of SMEs owners in Malaysia and Australia, Asian Social Science, 5(9).

NSDC. (2007). SME Annual Report 2007: National SME Development Council.

OECD. (2005) Oslo Manual: Guidelines for Collecting and Interpreting Innovation Data, 3rd edition.

Oke, A., Burke, G., \& Myers, A. (2003). Innovation types and their impact on performance in UK SMEs.

Penrose, E. T. (1959). The Theory of the Growth of the Firm. New York: John Wiley.

Praag, V. C. M. (2003). Business survival and success of young small business owners. Small Business Economics, 21(1), 1-17.

Roberts, D., Baker, S., \& Walker, D. (2005). Can we learn together? Co-creating with consumers. International Journal of Market Research, 47(4), 1-21.

Sathe, V. (2003). Corporate entrepreneurship: Top managers and new business Creation. Cambridge: University Press.

Sekaran, U., \& Bougie, R. (2010). Research Methods for Business: A skill Building Approach (5th ed). John Wiley and Sons Inc.

Singh, K. (2007). Quantitative social research methods. India, New Delhi: Sage Publications.

Siringoringo, H., Prihandoko, Tintri, D., \& Kowanda, A. (2009). Problems face by small and medium business in exporting products. Delhi Business Review, 10(2), 49-56.

SSM Annual Report. (2015). Retrieved from, http://www.ssm.com.my

SSM Annual Report. (2016). Retrieved from, http://www.ssm.com.my

SME Annual Report. (2015/2016). Retrieved from, http://www.smecorp.gov.my 
INTERNATIONAL JOURNAL OF ACADEMIC RESEARCH IN BUSINESS AND SOCIAL SCIENCES

Vol. 10, No. 2, Feb, 2020, E-ISSN: 2222-6990 @ 2020 HRMARS

Tan, K. S., Chong, S. C., Lin, B., \& Eze, U. C. (2009). Internet-based ICT adoption: Evidence from Malaysian SMEs. Industrial Management \& Data Systems, 109(2), $224-244$.

Thorton, P. H. (1999). The sociology of entrepreneurship. Annual Review of Sociology, 25, 19-46.

Timothy, L. P., \& James, A. W. (2007). SME performance: A case for internal consistency. Journal of Small Business Strategy, 18, 1.

UNDP. (2007). Malaysia Small and Medium Enterprises (Report). Kuala Lumpur: United Nations Development Programme.

US SBA. (2009). Starts and closures of employer firms, 2004-2008. Retrieved from, http://www.sba.gov

US SBA. (2014). Retrieved from, http://www.sba.gov

Praag, V. C. M. (2003). Business survival and success of young small business owners. Small Business Economics, 21(1), 1-17.

Varis, M., \& Littunen, H. (2010). Types of innovation, sources of information and performance in entrepreneurial SMEs. European Journal of Innovation Management, 13(2), 128-154.

Wan, D., Ong, C.H. \& Lee, F. (2005). 'Determinants of Firm Innovation in Singapore,' Technovation, 25(3), 261-8.

Wang, C. L., \& Ahmed, P. K. (2004), 'The Development and Validation of the Organizational Innovativeness Construct Using Confirmatory Factor Analysis,' European Journal of Innovation Management, 7(4), 303-13.

Zhuang, L., Williamson, D., \& Carter, M. (1999). Innovate or Liquidate - Are All Organisations Convinced: A Two-phased Study into the Innovation Process. Management Decision, [Online], vol. 37, no. 1, (n.p.), Available: http://www.emeraldlibrary.com/brev/00137ag1.htm. 